Mongolian Academy of Sciences
Mongolian Journal of Chemistry
Institute of Chemistry \& Chemical Technology

\title{
The Precious metals (Au, Ag, Pt, Pd, Rh) adsorption on the Silicon - organic sorbents
}

\author{
G. Burmaa ${ }^{1}$, S. Alen ${ }^{1}$, Yu. Ganchimeg ${ }^{2}$, I. Sukhbaatar ${ }^{2}$ \\ ${ }^{1}$ Institute of Chemistry and Chemical Technology, MAS \\ ${ }^{2}$ Mongolian University of Science and Technology, School of Materials Technology
}

\begin{abstract}
Sorption activity of two types of Silicon-organic sorbents for the previous metals has been studied. A polymer - poly (3- silsesquioxanilpropylthiocarbamate) - 3- silsesquioxanilpropylammonium which was obtained by the hydrolytic poly-condensation reaction and has been determined its physical, chemical characteristics and its sorption activity for the $\operatorname{Ag}(\mathrm{I}), \mathrm{Au}(\mathrm{III})$, $\mathrm{Pt}(\mathrm{IV}), \mathrm{Pd}(\mathrm{II}), \mathrm{Rh}(\mathrm{III})$. It has been found out that the sorbent shows high static sorption of Gold (III), Mercury (II) at acidic condition. The second a net structured silicon-organic copolymer $\left\{\mathrm{SiO}_{2} * 2\left[\mathrm{O}_{1.5} \mathrm{Si}\left(\mathrm{CH}_{2}\right)_{3} \mathrm{NHC}_{5} \mathrm{H}_{4} \mathrm{~N}\right\}_{\mathrm{n}}\right.$ was synthesized by hydrolytic co-poly-condensation reaction. It likely to react as an anionit that adsorbs chloro-complex anion of the $\mathrm{Au}$ (III), $\mathrm{Pt}(\mathrm{IV}), \mathrm{Pd}(\mathrm{II})$, $\mathrm{Rh}(\mathrm{III})$.
\end{abstract}

Keyword: dithiocarbamate, 2-aminopyridine, sorption capacity, ion-coordination.

\section{Introduction}

I nitial systemic research about the complexity and silicon-organic ionite which contain complex forming or ion exchange groups started since 1977, when discovered the polymercaptomethylsilsesquioxane's xerogel $[1,2]$. It was taken from hydrolytic polycondensation of the mercaptomethyltrialcosisilan $\mathrm{HSCH}_{2} \mathrm{Si}(\mathrm{RO})_{3}$ ( $\left.\mathrm{R} \quad=\mathrm{CH}_{3}, \quad \mathrm{C}_{2} \mathrm{H}_{5}\right)$. Poly-mercaptomethylsilsesquioxane's xerogel is an adsorbent that has ability to adsorb Mercury (II) from the extremely diluted solution (0.01$2 \mathrm{mg} / \mathrm{l} \mathrm{Hg}$ ) in the high diapason of the $\mathrm{pH}$, fully [3]. This adsorbent showed high selective adsorption of Mercury(II) from solution which contains over concentrated ions of the $\mathrm{Zn}(\mathrm{II}), \mathrm{Fe}(\mathrm{II}), \mathrm{Co}(\mathrm{II}), \mathrm{Ni}(\mathrm{II})$ at $\mathrm{pH}$ $0.3-3$. Now days this adsorbent is using for removal of Mercury from waste water of chlorine industry [3]. Also this sorbent has shown high activity (1.1mg-equa/g) in case of $\mathrm{Ag}(\mathrm{I})$ [4]. Then, adsorbed silver was fully desorbed by $0.25 \mathrm{M}$ ammonium hydroxide. When solution $\mathrm{pH}>3$, this sorbent has full sorption capacity for $\mathrm{Pb}(\mathrm{II})$ and $\mathrm{Sn}(\mathrm{II})$ and developed a spectrometer speedy method that used to determine these elements in spa water [4].

Therefore, silicon-organic sorbent (PTCA-3A) with dithiocarbamate group has been synthesized [5-7]. We are performing research evaluating of adsorption capacity of $\mathrm{Hg}$ (II), $\mathrm{Au}(\mathrm{III}), \operatorname{Ag}(\mathrm{I}), \mathrm{Pt}(\mathrm{IV}), \mathrm{Rh}(\mathrm{III})$ from aqueous solution .

Organic derivatives of the dithiocarbamate have been used widely in practice. Most of them have an unique biological activity and therefore, it is become raw material of the pharmacy [8]. There is a special trend of the practical usage of organic compounds with dithiocarbamate group for determination of heavy metals in the 
industrial waste water and its purification [9.10]. Also, there are different types of adsorbent materials which contain dithiocarbamate group and parts [11.12].

Silicon-organic complexities and ionits [13.14] have stability to high temperature (till $250^{\circ} \mathrm{C}$ ). But study of their ion exchange property is scarce and never been studied its practical usage.

Silicon-organic compounds with hetero-cycle ion has unique biological activeness. But poly-orginalsilsesquioxanes containing hetero-cycle in their organic radical are effective adsorbents which could form complex [7.17]. Therefore, we did research for eluvidation of precious metals $(\mathrm{Au}, \mathrm{Ag}, \mathrm{Pt}, \mathrm{Pd}, \mathrm{Rh})$ adsorption ability of the silicon-organic copolymer (PAPS-2) or $\left\{\mathrm{SiO}_{2} * 2\left[\mathrm{O}_{1.5} \mathrm{Si}\left(\mathrm{CH}_{2}\right)_{3} \mathrm{NHC}_{5} \mathrm{H}_{4} \mathrm{~N}\right\}_{\mathrm{n}} \quad\right.$ that contains 2-aminopyridin which was synthesized by the co-poly-condensation reaction [18].

\section{Experimental}

Materials. Poly(3-silsesquioxanil propylthiocarbamate) 3-silsesquioxanilpropyl ammonia (PTCA-3A) is a net constructed polymer with yellow color, finely dispersed powder. Silicon- organic copolymer PAPS-2 is brown colored and coarse sized powder. Table 1 shows physical and IR spectrum data of used polymers.

Table 1. Polymer (PTCA-3A) and PAPS-2

\begin{tabular}{|c|c|c|c|c|c|c|c|c|}
\hline \multirow[b]{2}{*}{$\begin{array}{l}\frac{\pi}{\vec{\Xi}} \\
\text { 范 }\end{array}$} & \multicolumn{6}{|c|}{ Physical data } & \multirow[b]{2}{*}{${ }_{Q}^{u}$} & \multirow[b]{2}{*}{$\begin{array}{l}\text { IR spectrum } \\
\quad\left(v, \mathrm{~cm}^{-1}\right)\end{array}$} \\
\hline & $\underbrace{\overbrace{0}^{\tilde{g}}}_{0}$ & $\underbrace{\frac{\overbrace{0}^{0}}{00}}_{0}$ & $\underbrace{\frac{\tilde{\sigma}_{0}^{0}}{\text { कह }}}_{0}$ & $\underbrace{8}_{0}$ & 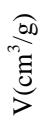 & 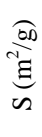 & & \\
\hline 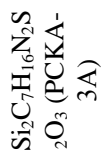 & $\stackrel{\mathbb{Z}}{\rightarrow}$ & $\stackrel{\infty}{n} \stackrel{\infty}{0}^{2}$ & $\stackrel{n}{n}$ & :̊. & ö & ' & సิ & $\begin{array}{c}3400,2930 \\
1540,1020(\mathrm{NH}) \\
2570(\mathrm{~S}-\mathrm{H}), 1340 \\
(\mathrm{C}=\mathrm{S}), 1100(\mathrm{Si}-\mathrm{O}- \\
\mathrm{Si})\end{array}$ \\
\hline 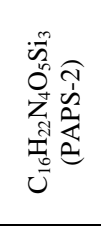 & ' & & ' & ' & ભે & $\frac{n}{n}$ & $\underset{\sim}{\sim}$ & $\begin{array}{c}3400,3300(\mathrm{NH}), \\
1615,1595,1480, \\
1440(\text { circle of the } \\
\text { Pyridine } \mathrm{C}=\mathrm{C}, \\
\mathrm{C}=\mathrm{N}), 1120- \\
1000(\mathrm{Si}-\mathrm{O}-\mathrm{Si}), \\
1560[\delta(\mathrm{NH})]\end{array}$ \\
\hline
\end{tabular}

$\mathbf{P}_{\overline{0}}-$ density, $\mathrm{P}_{\mathrm{n}}-$ pour density, $\mathrm{P}_{\mathrm{T}}-$ apparent density,

$\mathrm{P}_{\mathrm{A}}$ - porosity, $\mathrm{V}$ - total pore volume, $\mathrm{S}$ - surface area

IR spectrum of polymers before and after sorption of the precious and rare metal ions were obtained by using high purity $\mathrm{KBr}$ with Specord IR 75 and Specord M 80. Physical data were determined according to previous method [19].

Colour of polymer (PTCA-3A) is changing to yellow after adsorption of $\mathrm{Hg}$ (II) while with $\mathrm{Au}(\mathrm{III})$ - orange, $\mathrm{Pt}(\mathrm{IV})$ - yellowish, $\mathrm{Pd}(\mathrm{II})$ brown, $\mathrm{Rh}(\mathrm{III})$ - pink, $\operatorname{Ag}(\mathrm{I})$ - amber.

\section{Sorption method of the precious metals}

Sorption of $\mathrm{Hg}(\mathrm{II}), \mathrm{Au}(\mathrm{III}), \mathrm{Pt}(\mathrm{IV}), \mathrm{Pd}(\mathrm{II})$, $\mathrm{Rh}$ (III) was studied in hydrochloric acid with concentration of 0.1-5.0 mol/1 while $\operatorname{Ag}(\mathrm{I})$ sorption was studied in nitric acid with same concentration.

Polymers (PTCA-3A, PAPS-2) were taken $0.05 \mathrm{~g}$ of and mixed and shaked with solution of precious metal's chloro-complex in 0.1$5.0 \mathrm{~mol} / 1$ concentrated hydrochloric and nitric acids by shaker HY-4. Content of the metals in the solution was $0.05-0.8 \mathrm{mg} / \mathrm{ml}$. After a certain time polymer was separated from solution and washed thoroughly and concentration of metal ions left in the solution was determined by spectrophotometer method (HITACHI U-1000 and KFK-2) with tin chloride [20,21].

Precious metals absorption capacity of the of polymers was calculated by maximum content of the metal per gram of polymers at the equilibrium condition. .

Standard solutions of precious metals were prepared by dissolving of $\mathrm{AgNO}_{3}$; $\mathrm{H}[\mathrm{AuCl}] 4 \mathrm{H}_{2} \mathrm{O} ; \mathrm{H}_{2}\left[\mathrm{PtCl}_{6}\right] 6 \mathrm{H}_{2} \mathrm{O} ; \mathrm{PdCl}_{2}$ and $\mathrm{RhCl}_{3} 4 \mathrm{H}_{2} \mathrm{O}$ in distilled water.

\section{Result and Discussion}

\section{Sorption study of PTCA-3A polymer}

Adsorption $\operatorname{Ag}(\mathrm{I})$ and $\mathrm{Pd}(\mathrm{II})$ is correlated with acid concentration, while other ions have no direct correlation. However, $\operatorname{Ag}(\mathrm{I})$ and $\mathrm{Pd}(\mathrm{II})$ correlation shows reverse behaviour (Figs 1 and 2). Figures 1 and 2 indicate when $\operatorname{Ag}(\mathrm{I})$ is adsorbed from nitric acid, proton concentration is increased because of $\mathrm{H}^{+}$is interacting with sulfur atom of the thiolyate that caused decreasing $\operatorname{Ag}(\mathrm{I})$ adsorption. Sorption of $\left[\mathrm{PdCl}_{4}\right]^{2}$ and $\left[\mathrm{RhCl}_{6}\right]$ improved in 
result of increasing of chloride ions concentration in solution. Influence hydrochloric acid concentration on the $\mathrm{Au}(\mathrm{III})$ and $\mathrm{Hg}$ (II) sorption was much weaker than other ions.

It can be suggested that in acid solution thiocarbamate group of polymer (PTCA-3A) is interacting with acid molecule (HA) and reaching to equilibrium condition (equation 1.1).

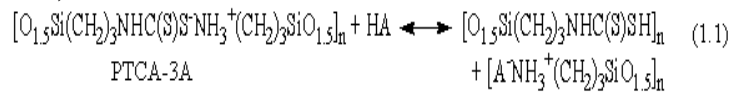

IR spectroscopy result indicated (not shown) peak at $1500 \mathrm{~cm}^{-1}$ is related in asymmetric fluctuation of $\mathrm{NH}_{3}{ }^{+}$group of the polymer (PTCA-3A) which showed in the equation 1.1. After sorption in nitric acid there appeared a new peak at $1380 \mathrm{~cm}^{-1}$. It proves that nitrate ion was entered into structure of the polymer.

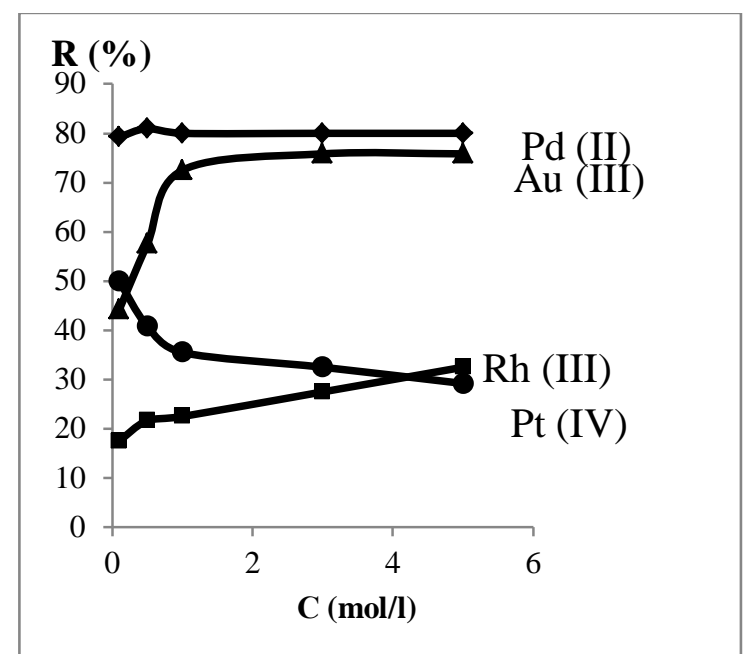

Figure 1. Influence of the acid concentration on sorption of $\mathrm{Au}(\mathrm{III}), \mathrm{Pt}(\mathrm{IV})$ and $\mathrm{Rh}(\mathrm{III})$

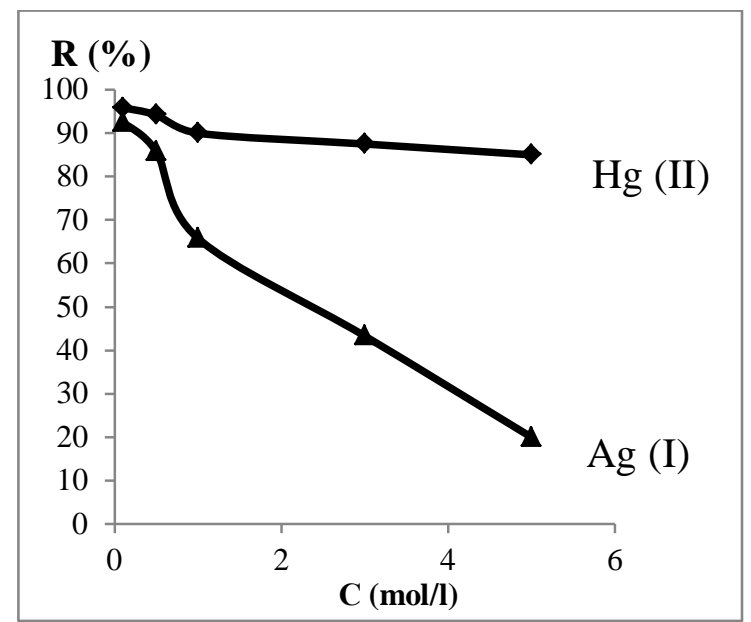

Figure 2. Influence of the acid concentration on sorption $\mathrm{Ag}(\mathrm{I}), \mathrm{Hg}(\mathrm{II})$
A solution $\mathrm{pH}$ increased a little due to protonation of functional group of polymer (PTCA-3A). This behaviour of the polymer (PTCA-3A) in acid solution shows its functional group has ion-coordination property. Also determines influence of acid concentration on metal ions sorption (Figure1and 2). In the matter sorption of the $\mathrm{Hg}$ (II) and $\operatorname{Ag}(\mathrm{I})$ ions occurred by ioncoordination mechanism and possibly was interacted with both 2 atoms of the sulfur (equation 1.2):

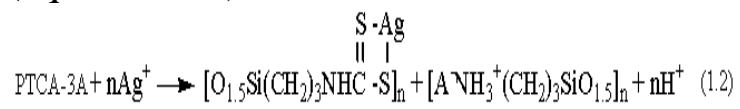

In the IR spectra of polymer (PTCA -3A) saturated by $\mathrm{Hg}(\mathrm{II})$ and $\mathrm{Ag}(\mathrm{I})$ ions, disappeared peaks at $1340(\mathrm{C}=\mathrm{S})$ and 2570 $(\mathrm{S}-\mathrm{H}) \mathrm{cm}^{-1}$ an indication of mechanism shown in equation 1.2 takes place. There weren't shown any changes in amine $\left(1540 \mathrm{~cm}^{-1}\right)$ and amino $\left(1500 \mathrm{~cm}^{-1}\right)$ groups fluctation.

Desorption of the $\mathrm{Hg}^{2+}$ and $\mathrm{Ag}^{1+}$ cations by $6 \mathrm{M}$ solution of nitric acid indicates that they were adsorbed by ion exchange mechanism.

Functional groups of the polymers could be interacted with $\mathrm{AuCl}_{4}^{-}, \mathrm{PtCl}_{6}{ }^{2-}, \mathrm{PdCl}_{4}{ }^{2-}$ and $\mathrm{RhCl}_{6}^{2-}$ via atoms of the nitrogen and sulfur. In the IR spectra of polymers saturated with these ions disappeared peak at $1500 \mathrm{~cm}^{-1}$ $\left(\mathrm{NH}_{3}{ }^{2+}\right)$. Also there were not appeared any peaks associated with the other forms of precious metals in the polymer matrix. Elemental analysis indicated that polymer (PTCA-3A) in acid solution contains $\mathrm{Au}$ and $\mathrm{Pd}$ as $\mathrm{AuCl}$ and $\mathrm{PdCl}_{0.5}$. This shows these element atoms are connected with no less than 3 atoms of functional groups (coordination number 4 ). In the spectrum of polymer saturated with ions $\mathrm{Au}(\mathrm{III}), \mathrm{Pt}(\mathrm{IV})$, $\mathrm{Pd}(\mathrm{II})$ and $\mathrm{Rh}(\mathrm{III})$ disappeared peak at $1340 \mathrm{~cm}^{-1}(\mathrm{C}=\mathrm{S})$ and peaks of the amine group at 3400 and $1540 \mathrm{~cm}^{-1}$ were shifted to high wave numbers region. These results and low desorption values (not more than 5-10\%) of gold, platinum, palladium, rhodium by hydrochloric and nitric acid solutions (6-9 
mol/l) showed that acido-complexes of these metals interacting via ion-coordination mechanism with sulfur atom of thion group and nitrogen atoms of ammonium and amine group. There is chance of ammonium group participation decrease in adsorption of precious metals with increase of hydrochloric acid concentration. Gold and palladium in hydrochloric acid with concentration of 5 mol/l exist as $\mathrm{AuCl}_{2}$ and $\mathrm{PdCl}_{2}$.

Static sorption capacity (SSC) was determined in $3 \mathrm{~mol} / \mathrm{l}$ acid solution. Connection degree of active group of the polymer (PTCA-3A) was determined by comparison of static sorption capacity value with theoretical sorption capacity value (SSC·100/TSC) and showed in

Table 2.

Table 2. SSC, TSC and ratio to connect with chemical active group of PTCA-3A sorbent

\begin{tabular}{|c|c|c|c|c|c|c|}
\hline Volume & $\begin{array}{c}\mathrm{Rh}(\mathrm{I} \\
\mathrm{II})\end{array}$ & $\mathrm{Pt}(\mathrm{IV})$ & $\mathrm{Pd}(\mathrm{II})$ & $\mathrm{Au}(\mathrm{III})$ & $\mathrm{Ag}(\mathrm{I})$ & $\mathrm{Hg}(\mathrm{II})$ \\
\hline SSC, $\mathrm{mg} / \mathrm{g}$ & 26 & 86 & 122 & 300 & 160 & 400 \\
\hline TSC, $\mathrm{mg} / \mathrm{g}$ & 340 & 660 & 350 & 650 & 370 & 658 \\
\hline $\begin{array}{c}\text { SSC. } 100 / \mathrm{TSC} \\
(\%)\end{array}$ & 9.0 & 14.0 & 33.0 & 45.0 & 46.0 & 59.0 \\
\hline
\end{tabular}

Connection degree of active group of polymer was increased as: $\mathrm{Rh}(\mathrm{III})<\mathrm{Pt}(\mathrm{IV})<\mathrm{Pd}(\mathrm{II})<\mathrm{Au}(\mathrm{III})<\mathrm{Ag}(\mathrm{I})<\mathrm{Hg}$ (II) . This result is in agreement with the previous published reference [22]. It also shows direct dependence with the metal sulfides solubility. Adsorption equilibrium time in hydrochloric and nitric acids with $3 \mathrm{~mol} / \mathrm{l}$ were for $\mathrm{Pd}(\mathrm{II})$ 1.5h, Au(III)-2h, Hg(II)-2h, Ag(I)- 3h, Pt(IV)$3 \mathrm{~h}$ and $\mathrm{Rh}(\mathrm{III})-3 \mathrm{~h}$, respectively. Poly (3silsesquioxanilpropylthiocarbamate)3-

silsesquioxanilpropylammonium has high adsorption capacity to gold and mercury from acid solution and its static sorption capacity SSC is not less than silicon-organic and organic sorbents which studied previously [57,22].

\section{Sorption study of copolymer(PAPS-2)}

This silicon-organic copolymer's Au(III), $\mathrm{Pt}(\mathrm{IV}), \mathrm{Pd}(\mathrm{II}), \mathrm{Rh}(\mathrm{III})$ sorption activity was determined in the hydrochloric acid solution with concentration of $0.1-0.5 \mathrm{~mol} / \mathrm{l}$. Their sorption activity was the highest in hydrochloric acid solution with concentration of less than $1 \mathrm{~mol} / \mathrm{l}$. When acid concentration is more than $1 \mathrm{~mol} / 1$, the precious metals sorption (R\%) was decreased considerably (Figure $3 \mathrm{a}, \mathrm{b}$ ). When temperature of solution increased from $20^{\circ} \mathrm{C}$ to $40^{\circ} \mathrm{C}$ there wasn't any change in sorption behaviour of metals (Figure 3a,b) as well as in equilibrium time. Equilibrium time in $0.5 \mathrm{M} \mathrm{HC}$ at $20^{\circ} \mathrm{C}$ and $40^{\circ} \mathrm{C}$ was similar i.e $20-40 \mathrm{~min}$. Static sorption capacity and coefficient of interphase distribution $\left(\mathrm{D}, \mathrm{cm}^{3} / \mathrm{g}\right)$ were calculated based on isotherm curves of sorption and showed in Table 3.
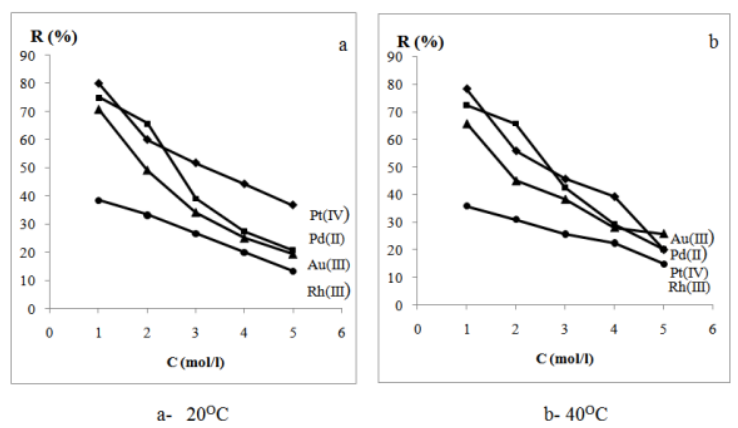

Figure 3. Influence of the hydrochloric acid concentration on metal sorption.

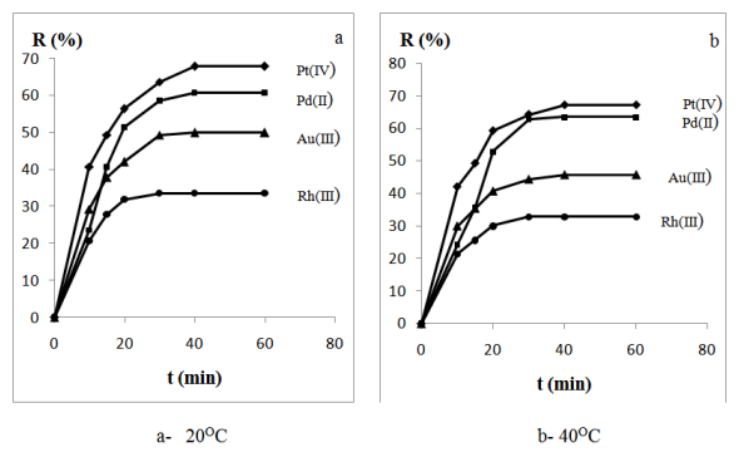

Figure 4. Influence of equilibrium time on the metals sorption.

Table 3. Static sorption capacity (SSC, mg/g) and coefficient of interphase distribution $\left(\mathrm{D}, \mathrm{cm}^{3} / \mathrm{g}\right)$ of the copolymer (PAPS-2)

\begin{tabular}{|l|l|l|l|l|}
\hline Data & $\mathrm{Au}(\mathrm{III})$ & $\mathrm{Pt}(\mathrm{IV})$ & $\mathrm{Pd}(\mathrm{II})$ & $\mathrm{Rh}(\mathrm{III})$ \\
\hline $\mathrm{SSC}, \mathrm{mg} / \mathrm{g}$ & 134.0 & 141.0 & 124.0 & 110.0 \\
\hline $\mathrm{D} \cdot 10^{3} \mathrm{~cm}^{3} / \mathrm{g}$ & 4.3 & 5.4 & 2.8 & 1.3 \\
\hline
\end{tabular}

The result shown in Table 3 indicated that it's possible to separate precious metals with a micro content in solution by polymer (PAPS- 
2). Metals adsorbed on the polymer (PAPS-2) can be desorbed by $6 \mathrm{~mol} / \mathrm{l}$ hydrochloric acid solution. When desorption is done at room temperature, $1 \mathrm{ml}$ desorbent was capable to desorb 120 ppm Au, 190 ppm Pt, 90 ppm Pd and $35 \mathrm{ppm} \mathrm{Rh}$, respectively.

\section{Sorption mechanism}

Precious metals are adsorbed on the polymer (PAPS-2) according to the anion exchange mechanism. Elemental analysis of the polymer saturated with the precious metals showed adsorption occurs in form of $\left[\mathrm{MCl}_{\mathrm{n}}\right]^{\mathrm{n}-}$ ${ }^{\mathrm{k}}$ where M-metal, n-4,6, k- oxidation degree of metal. Adsorption occurred according to ion exchange mechanism and it has been supported by decrease of adsorption activity with increasing of acid concentration. This polymer didn't show any capacity to adsorb silver and copper in acid solution. In acid solution $\mathrm{Ag}(\mathrm{I})$ and $\mathrm{Cu}(\mathrm{II})$ are presented in cation type and it's one more evidence that PAPS-2 acts as an anionit in acid solution. Sorption activity of the PAPS-2 is similar with pyridine based organic sorbents [23].

In order to find out either nitrogen atom of pyridine circle or amine group is participating in anion exchange process were taken comparative IR spectrums of the pure and saturated with precious metals polymer. In the pure polymer (PAPS-2) IR spectrum were found peaks at 1615, 1600, 1485, $1440 \mathrm{~cm}^{-1}$ due to $-\mathrm{C}=\mathrm{C}$ - and $-\mathrm{C}=\mathrm{N}$ - groups of pyridine and also peak at $1560 \mathrm{~cm}^{-1}$ due to deformation fluctuation of the NH group. In the spectrum of polymer (PAPS-2) saturated with metal ions was disappeared $\mathrm{NH}$ group peak and a clear change in $-\mathrm{C}=\mathrm{C}$ - and $-\mathrm{C}=\mathrm{N}$ - groups (peaks at 1600 and $1495 \mathrm{~cm}^{-1}$ were widened). Such clear changes in IR spectrum indicated in anion exchange were participated both nitrogen atom of pyridine and amine group and it can be showed according to equation 1.3 .

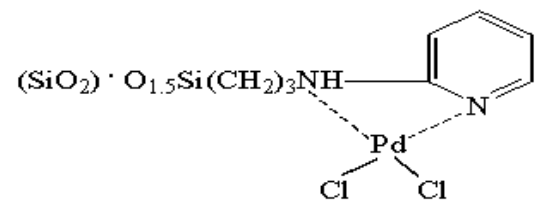

(1.3)

Simultaneously with anion exchange occurred substitution of 2 chlorine atoms with the polymer functional group and formation of the coordination bond with nitrogen atoms (example: Palladium acido-complex $\left[\mathrm{PdCl}_{4}\right]^{2-}$ ) .

\section{Conclusions}

The application of PTCA-3A and PAPS-2 polymers for sorption of precious metals was studied. Based on the experimental results following conclusion can be drawn:

* Sorption of $\mathrm{Au}(\mathrm{III}), \mathrm{Ag}(\mathrm{I}), \mathrm{Pt}(\mathrm{IV}), \mathrm{Pd}(\mathrm{II})$ and $\mathrm{Rh}(\mathrm{III})$ by silicon-organic polymers depend on the concentration of acids. The best result was obtained for concentration of 0.1 and $1 \mathrm{~mol} / \mathrm{l}$. Sorption efficiency decreases with the increase of acid concentration.

* Silicon-organic polymers can be used efficiently for removal of a large amount of precious metals from aqueous solutions.

\section{References}

1. A.s. SSSR № 585187. Prostranstvenno-sshitii polymer dlya cationoobmennikov i redoxitov / L.P. Phenn, E.B. Slenyakova, M.G. Voronkov, N.N. Vlasova, Ph.P. Kletsko // B.E. 1977. № 47. p. 85.

2. Phenn L.P., Slenyakova E.B., Voronkov M.G., Vlasova N.N., Kletsko Ph.P. Kirrilov A.E., Shklyar T.V. DAN SSSR. 1977. T. 236. № 6. p. 1426-1429.

3. Kirrilov A.E., Zemlyanushnova O.V., Vlasov N.N., Voronkov M.G., Slenyakova E.B., Phenn L.P. JACh. 1982. T. 37. № 7. p. 1201-1204.

4. Zemlyanushnova O.V., Kirrilov A.E., Golentovskaya E.P., Vlasova N.N. Chem. and Chem. Techn.. № 5. p. 568-571.

5. Burmaa G., Vlasova N.N., Pestunovich A.E., Pojedaiv Yu.N., Voronkov M.G. " SO RAN, ser. chem. science". 1992. Edi. 4. p. 89-94.

6. Burmaa G., Pojedaiv Yu.N., Pestunovich A.E., Vlasova N.N., Voronkov G.M. Thesis docladov 8-th soveshaniya. Sankt-peterburg. 1992. p.51.

7. Voronkov M.G., Vlasova N.N., Pozhidaev Yu.N. "Appl. Organomet. Chem. 2000. V. 14. p. 287-303.

8. Yilmgaz V.T., Yazicilar T.K., Cesur H. et al. "Synth. and React. Inorg. And 
Metal-Org. Chem. 2003. V.33. N 4. p.589-605.

9. Mehmet Ya. "JACh". 2003. T.58. № 5. p. 513-516.

10. Erven C.A. "Metal Finish". 2001. V. 99. N1. p. 8-19.

11. Denizli A., Kesenci K., Arica Y., Piskin E. "React. and Funct. Polym". 2000. V. 44. N 3. p. 235-243.

12. Venkatesan K.A., Srinivasan T.G., Vasudeva R.P.R. "Separ. Sci. and Technol. 2002. V. 37. N 6. p. 14171429.

13. A.s. SSSR № 429074. Sposob polucheniya kationitov / S.E. Vasyukov, K.P. Grinevich, M.V. Sobolevskii, A.Ya. Tagirov, E.A. Chernishov, E.Ph. Bugrenko, T.L. Krasnova, G.P. Matveicheva, E.A. Rogachevskii // V.E. 1974. № 19. S. 80.

14. A.s. SSSR № 523911. Sposob polucheniya kationitov / S.E. Vasyukov, A.E. Demchenko, E.Ph. Bugrenko, A.s. Ananieva, E.A. Chernikov // V.E. 1976. № 28. p. 69.

15. Triphomavo O.M., Chernov N.Ph., Voronkov M.G. "Suc. chem. 1999. T. 68. Edi. 4. s. 318-330.
16. Voronkov M.G., Chernov N.F., Baigozhin A. "J. Coated Fabrics. 1999. Vol. 29. N 1. P. 75-88.

17. Voronkov M.G., Vlasova N.N., Pojidaev Yu.N. “JPH. T. 69. № 5. p. 705-718.

18. G Burmaa, N.N.Vlasova, Yu.N.Pojidaev, M.G.Voronkov, S. Alen, Yu.Ganchimeg "Erdem shinjilgeenii byteeliin emkhetgel" SHUTIS, 2011, № 3/115, p.

19. Iyvazov B.V. Praktikum po khimii poberkhnostnikh yavlenii i adsorbtsii. M.: High school. 1973. 208 s.

20. Marchenko Z. Photometricheskoe opredelenie elementov. M.: Mir, 1971. 540p.

21. Probootbiranie i analiz blagorodnikh metallov: Spravochnik /In red. E.Ph. Barishnekova. M.: Metallurgy, 1978. 430p.

22. Murinov Yu.E., Maistrenko V.A., Afzaletdinova N.G. "Extraktsiya metallov S,N-organicheskimi soedineniyami”. M.: science, 1993. 192p.

23. Saldaze K.M., Kopilova-Valova V.D. Komplexoobrazyushie ioniti.M.: Chemistry, 1980. 336p. 